\title{
Ghrelin, Reward and Motivation
}

\author{
John R.W. Menzies ${ }^{a} \cdot$ Karolina P. Skibickab $•$ Gareth Leng ${ }^{a}$ • \\ Suzanne L. Dickson ${ }^{b}$ \\ ${ }^{a}$ Centre for Integrative Physiology, School of Biomedical Sciences, University of Edinburgh, Edinburgh, UK; \\ ${ }^{b}$ Department of Physiology/Endocrinology, Institute of Neuroscience and Physiology, The Sahlgrenska \\ Academy at the University of Gothenburg, Gothenburg, Sweden
}

\begin{abstract}
Almost all circulating gut peptides contribute to the control of food intake by signalling satiety. One important exception is ghrelin, the only orexigenic peptide hormone thus far described. Ghrelin secretion increases before meals and behavioural and electrophysiological evidence shows that ghrelin acts in the hypothalamus via homeostatic pathways to signal hunger and increase food intake and adiposity. These findings strongly suggest that ghrelin is a dynamically regulated peripheral hunger signal. However, ghrelin also interacts with the brain reward pathways to increase food intake, alter food preference and enhance food reward. Here we discuss ghrelin's role as an endocrine gut-brain reward signal in relation to homeostatic and hedonic feeding control.
\end{abstract}

Copyright $\odot 2013$ S. Karger AG, Basel

We are bombarded fairly steadily by reports of a high and rising incidence of obesity. Being obese is not in itself a problem but the consequences of obesity, like type 2 diabetes, cardiovascular diseases and some cancers, are of concern. Food intake is controlled by the brain but what, how much and how often we eat is not only driven by homeostatic requirements for calories and nutrients. The existence of what is now labelled an obesity epidemic is evidence that many people must have a strong drive to eat even when homeostatic signals indicate a positive energy balance in the form of large fat stores. However, we do not eat only for energy and nutrients, we also eat for pleasure. The target for hedonic-driven eating is a broad category of palatable foods with certain characteristics in common. Unfortunately, the foods we enjoy the most tend not to be nutritionally balanced, but are high in sugar, fat, salt and calories. What is more, hedonic desire for palatable foods can easily inundate the homeostatic mechanisms that normally delay the start or signal the termination of feeding. Thus, rewarddriven feeding may drive and support overeating, weight gain, obesity and illness. 
How might this happen? There are several possibilities - firstly, changes in the reward system may be a secondary effect of the onset or maintenance of obesity. The central signal most strongly associated with the reinforcing effects of palatable food is dopamine released from the mesolimbic structures. In humans, striatal dopamine receptor number is reduced in obesity [1] and this may be linked to a blunting of the normal reward response to food. When neural activity in the striatum is monitored in response to palatable food ingestion, individuals show reduced reward responses to an identical stimulus after having gained weight [2]. Secondly, and perhaps in contrast to this neuroadaptive reprogramming theory, a pre-existing genetic or epigenetic susceptibility or sensitivity to reward may exist. For example, striatal D2 receptor expression shows interindividual differences related to body weight. But rather than an obesity-driven mechanism, inherent differences in expression of the A1 allele of the TaqIA polymorphism may underlie this [3]. Selectively bred lines of obesity-prone rats (whose phenotypes presumably reflect subtle genetic differences from obesityresistant rats) show several impairments in proteins involved in dopamine neurotransmission. These are evident before exposure to a palatable diet or excess weight gain [4]. Thirdly, the consumption of palatable food may be considered to be a form of addiction. In experiments loosely parallel to those of Olds [5] where rats crossed electrified grids to self-stimulate their brain reward centres, rats made obese by chronic access to palatable food will continue to eat such food even when conditioned to associate its consumption with a painful electric shock [6]. In other words, rewardrelated stimuli may compel the consumption of palatable food even in the face of marked negative outcomes, real or potential - a classical attribute of addiction [7]. None of these three possibilities are mutually-exclusive and other aspects of the reward system may also be important. It is not yet clear whether reward-related obesity may be a consequence of hyper- or hypoactivity of the reward system. However, there may be strong parallels with other addictive disorders. Hyperactivity of the reward system likely drives initial overconsumption of rewarding food but then the behaviour becomes reinforced and habitual rather than enjoyable. A hedonic deficit may develop which is compensated for by increased motivation or a craving for the rewarding food. This may result in sustained 'wanting' in the absence of 'liking'. In other words, eating without pleasure.

In any case, the power of the reward system over feeding behaviour should not be underestimated. Compared with homeostatic mechanisms of feeding, much less is currently known about how hedonic systems in the brain influence food intake. It is clear, however, that hormonal peptide signals converge on certain brain regions and are pivotal in both homeostatic and hedonic feeding. Ghrelin is a naturally occurring peptide that is found in several regions of the body, including the brain, but is predominantly synthesised in the mucosal cells of the stomach. Ghrelin is secreted into the blood, levels rise during periods of energy depletion, including between normallyspaced meals, and fall upon feeding. Ghrelin acts centrally to signal hunger and, via well-characterised hypothalamic pathways, increases food intake in humans and ro- 
dents [8]. In addition, accumulating evidence points to a role for ghrelin in the modulation of motivation and reward, not only in feeding but also in responses to artificial rewards such as alcohol. Here, we review the target reward pathways for ghrelin, the receptors and neurobiological substrates of importance for ghrelin's effects on food intake, food reward and food motivated behaviour.

\section{Ghrelin's Influence on Central Reward Pathways}

The central reward pathways comprise multiple interconnected brain regions many of which are sensitive to hormonal peptides commonly associated with the control of homeostatic feeding [9]. The best-characterised pathway (now approaching 'classical' status) is the dopaminergic innervation of the nucleus accumbens (NAcc) by neurones in the ventral tegmental area (VTA). Other regions, especially the target sites of the NAcc such as the prefrontal cortex and ventral pallidum, and inputs into the NAcc such as the amygdala, are also important for reward processing. Other regions implicated in ghrelin signalling such as the lateral and ventromedial hypothalamus and the arcuate nucleus also form neurocircuits with the reward pathways that are likely to be important in integrating feeding control [10]. The ghrelin (GHS-R1A) receptor is localised in many brain regions associated with pleasure, reward and motivation. An early report noted GHS-R1A receptor mRNA expression in the substantia nigra and VTA and speculated whether receptor localisation in the reward pathway may indicate a role for the then-unidentified endogenous ligand in hedonic motivation [11]. Further evidence comes from studies using biotin-labelled ghrelin which binds to VTA neurones with a similar pattern of distribution seen to GHS-R1A receptor immunoreactivity [12]. GHS-R1A mRNA is translated to express functional ghrelin receptors in VTA neurones and ghrelin administration to this region causes dopamine release [12,13], although this may be dependent on feeding state [14]. Ghrelin excites VTA neurones in brain slices in vitro [12] and increases dopamine activity (as measured by the DOPAC:dopamine ratio or by microdialysis to directly measure dopamine release in the NAcc) in wild-type and ghrelin knockout mice but not in GHS$\mathrm{R} 1 \mathrm{~A}$ receptor knockout mice $[12,13,15]$.

\section{Ghrelin and Natural Rewards: Food and Sex}

Readers of this book hardly need to be reminded of ghrelin's central role in food intake. However, the discovery of the peptide solved an apparent mystery. Initially, the presence of GHS-R1A receptors in brain regions associated with food intake was not easily explained, particularly as most interested parties considered this receptor to be the target for a class of synthetic growth hormone secretagogues and, as such, are presumably mainly involved in the control of growth hormone secretion by an endoge- 
Fig. 1. A simplified illustration of brain regions sensitive to ghrelin. Ghrelin is secreted from the stomach into the blood to activate at least two distinct brain pathways involved in feeding. Activation of the homeostatic hypothalamus drives food intake. In addition to food intake, activation of hedonic pathways can also affect motivation and anticipation for food.

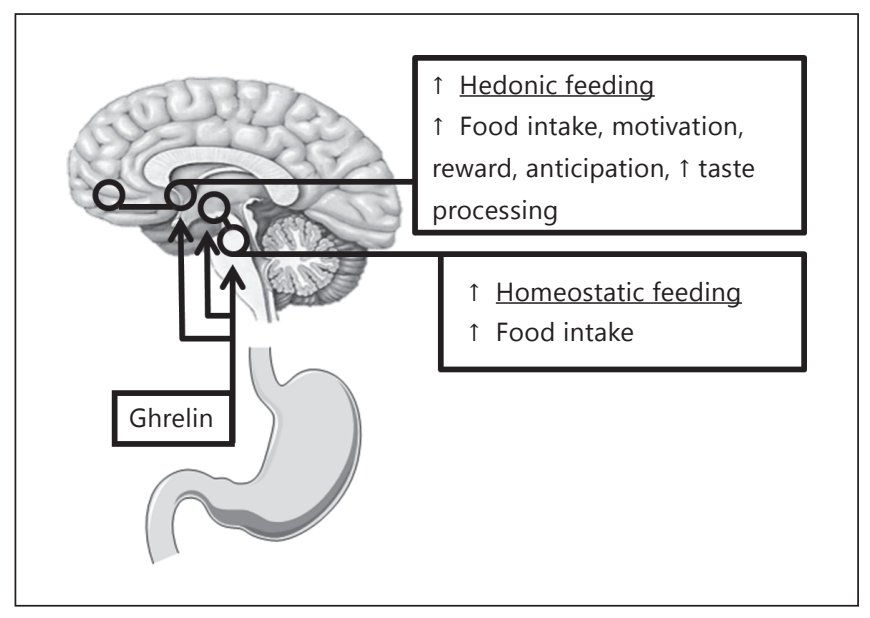

nous ligand. Aware of the localisation of somatostatin- and GHRH-containing neurones for example, most expected a hypothalamic source for an endogenous GHSR1A ligand, perhaps released from neuroendocrine cells into the blood to target somatotrophs. The finding that ghrelin was synthesised in and secreted from the stomach was unanticipated, even by its discoverers $[16,17]$. The peptide's localisation in the stomach and the localisation of GHS-R1A receptors in the arcuate and ventromedial nuclei drove a clear research direction addressing potential roles in food intake. Very soon ghrelin was shown to have effects on food intake, body weight and body composition in rodents [18-20] and evidence for changes in obese or anorexic humans followed $[21,22]$. Several years' productive effort was focused on ghrelin's role in the homeostatic control of feeding, mainly via its direct excitatory action at orexigenic NPY/AgRP/GABA neurones in the hypothalamic arcuate and ventromedial nuclei. Latterly though, attention has turned to the reward pathway as an important target $[9,23]$.

Ghrelin induces an acute orexigenic response when administered peripherally [24] or directly into the brain ventricles [25]. In 2005, Naleid et al. [27] demonstrated an orexigenic response following direct administration of low doses of ghrelin into the VTA and also the NAcc [26], a finding that we have since been able to replicate. This was the first indication that ghrelin may provide a gut-brain reward signal that is linked to feeding control at the level of the reward system. It seems rather likely that ghrelin accesses these reward circuits, especially as peripheral ghrelin injection has been shown to increase accumbal dopamine release [13]. The afferent stimulus provided by ghrelin could also be derived centrally, although it remains much debated whether ghrelin is produced in the brain as many research groups, including our own, have been unable to detect ghrelin mRNA in the brain by in situ hybridization. It can also be questioned whether an afferent ghrelin signal is required for GHS-R1A activation as the receptor appears to have constitutive activity in the absence of ligand [28] 


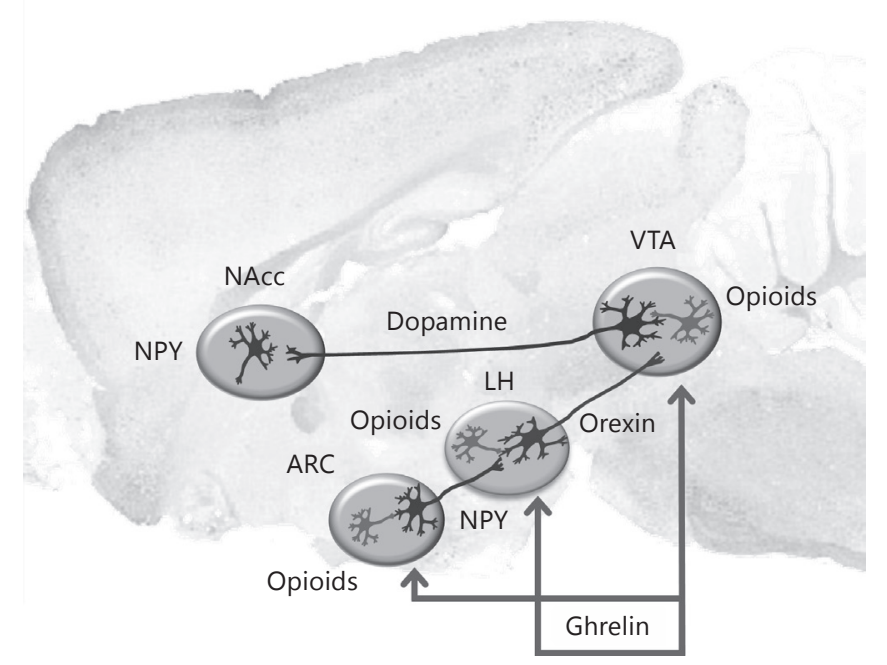

Fig. 2. Schematic illustration of brain pathways mediating ghrelin's effects on food motivation. A key pathway involved in food motivation is the midbrain dopamine projection from the VTA to the NAcc. Ghrelin appears to activate this pathway directly at the level of the VTA. This provides a potential mechanism for ghrelin to promote food intake even when homeostatic hypothalamic centres such as the arcuate nucleus (ARC) or lateral hypothalamus (LH) indicate a state of satiety. It is also possible that ghrelin affects food motivation indirectly, for example, by activating an afferent pathway. Recent studies suggest that while central opioid (via the mu receptor) and NPY (Y1 receptor) signalling are required for ghrelin's effects on food motivation, the targets sites for these effects differ. At the level of the VTA, opioid signalling (but not NPY signalling) is required for ghrelin's effects on food motivation [39].

and may be able to modify dopamine signalling by heterodimerising with dopamine D1 receptors in, for example, ghrelin-sensitive neurones in the VTA [29].

The basic goal of feeding is to acquire calories and a diversity of nutrients. There is an obvious advantage in being able to detect a food high in energy, and one excellent indicator of this nutritional property is sweetness. Mammals appear to have an innate pre-disposition to preferentially eat sweet foods. Remarkably, rats trained to make a mutually exclusive choice between a behaviourally effective i.v. dose of cocaine or a short period of access to a sweet drink show a strong and sustained preference for the sweet taste [30]. Evidence suggests that ghrelin signalling may play an essential role in the motivation to consume sweet food over bland food. When given a free choice between bland food or sweet, palatable, energy-dense food, GHS-R1A receptor knockout mice and mice treated with a GHS-R1A receptor antagonist eat less palatable food than controls. Furthermore, palatable food consumption is usually associated with an increase in dopamine release in the NAcc but this is not observed in GHS-R1A knockouts [31]. In mice, the ability of sweet chocolate treats to condition a place preference is abolished by peripheral treatment with a GHS-R1A receptor antagonist [31] and is absent in fasted GHS-R1A receptor knockout mice [32]. Access to a pelleted high-fat 
rodent diet also conditions a place preference in mice. This is enhanced by ghrelin administered peripherally but GHS-R1A receptor knockout mice show no such preference [33].

Building on serendipitous findings by Constantin Fahlberg in 1878, chemists are now able to produce molecules that are many hundred times sweeter than sucrose. These can therefore be used at very low concentrations, low enough to provide next to non-metabolisable energy. Saccharin is the prototypical artificial sweetener and rats will preferentially consume sweet-tasting saccharin solutions over water [34] but not in preference to approximately equally sweet natural, calorific sugars [35]. This gives rise to the idea of at least two aspects of reward driven by differing qualities in different foods; a gustatory reward (the pleasure of taste) and a post-ingestive reward (the pleasure associated with changes in plasma nutrient or hormonal levels). In addition to increasing sweet, caloric food intake, ghrelin also enhances sweet, non-caloric saccharin intake both in the presence and absence of caloric food. Also, consumption of a saccharin-sweetened food is reduced in GHS-R1A knockout mice compared to wild-type mice [36].

If an animal finds food rewarding, it will show motivated behaviour to obtain it. This can be demonstrated in an operant conditioning paradigm in which rats must work progressively harder in order to obtain a sweet treat. Motivated behaviour for a sucrose reward is increased by ghrelin given centrally or peripherally to satiated rats and, conversely, is suppressed in hungry rats by a GHS-R1A antagonist, also administered by these routes [37]. Indeed ghrelin administration directly to the VTA, but not the NAcc, increases food-motivated behaviour, thereby identifying the VTA as the primary target for these effects of ghrelin [37]. Consistent with this, chemical lesion of the VTA reduces ghrelin-evoked food-motivated behaviour [38]. Using the same operant self-administration model of motivation for sucrose, pharmacological blockade of NPY receptors with intracentroventricular administration of a selective Y1 receptor antagonist prevents a ghrelin-evoked increase in motivation. This observation is recapitulated with an opioid receptor antagonist. In contrast, ghrelin's local effects in the VTA on intake of normal bland food are unaffected by opioid receptor antagonism but are reduced by Y1 receptor blockade [39]. Interestingly, intra-VTA infusion of NPY antagonist does not prevent the potentiating effect of ghrelin on motivation suggesting that NPY activation to increase food motivation is at an extraVTA site, possibly the lateral hypothalamus or NAcc [39]. Taken together, this indicates that central NPY and opioid receptor activation is required for ghrelin's enhancement of sucrose motivation, but that in the VTA only opioid receptors are utilised by ghrelin for this response.

An important aspect of feeding-related behaviour is locomotion. An animal must forage or hunt for food before it can eat it. Ghrelin increases locomotion in mice when given centrally into the third ventricle [15] or more locally in the VTA or LDTg [13, 31]. Rats fed for a restricted period each day quickly develop food-entrained anticipatory activity (FAA) where a marked increase in locomotion is seen several hours pri- 
or to the time food is expected. Plasma ghrelin levels are specifically increased during a conditioned period of FAA in rats and physical activity levels can be reduced by intracebrovascular injection of a GHS-R1A receptor antagonist prior to the expected FAA [40]. Furthermore, decreased levels of FAA are observed in GHS-R1A receptor knockout mice. As well as conditioning FAA by restricted access to normal food, FAA can be evoked by restricted presentation of a palatable food in addition to ad lib access to normal food. When rats are given restricted access to a small amount of chocolate they show FAA similar to that seen in food-restricted animals and plasma ghrelin levels are elevated compared to rats not anticipating the palatable reward. In addition, intracebrovascular ghrelin increases FAA for a reward while intracebrovascular administration of a GHS-R1A receptor antagonist decreases it [41]. Thus, ghrelin appears to have a role in anticipatory activity for food, both predicted meals when hungry and predicted additional food rewards when satiated.

What cellular and molecular mechanisms might underlie this important role for ghrelin in reward and motivation? After chronic intracebrovascular ghrelin administration in rats, VTA dopamine D5 receptor mRNA and nicotinic acetylcholine $\mathrm{nACh}$ $\mathrm{Rb} 2$ receptor mRNA expression are increased whereas in the NAcc, there is reduced mRNA expression of dopamine D1A, D3 and D5 receptors and reduced expression of nicotinic acetylcholine $\mathrm{nAChRa} 3$ receptors [37]. Acute ghrelin administration to the VTA also upregulates opioid receptor mRNA in VTA neurones [39]. While it remains to be determined whether these molecular-level changes are simply compensatory responses to an enhanced dopamine signal for example, it is possible they could directly contribute to the rewarding effects of ghrelin. An increase in opioid receptor expression may underlie the interaction between ghrelin and opioids in the VTA, where a reward stimulus can elicit opioid release and concurrent ghrelin sensitises the VTA neuronal response to opioids by increasing opioid receptor expression. The presence of ghrelin could, therefore, make the stimulus of a single food reward much more motivating.

Less evidence exists for a role for ghrelin in modifying food reward in humans. Experiments measuring hunger or the wanting and liking of foods in human subjects can be contentious, relying as they often do on subjective experience or self-reporting. However, in an fMRI study using satiated human subjects exposed to images of palatable foods, ghrelin increased a BOLD response in likely neural correlates of reward pathway activation such as the amygdala, orbitofrontal cortex and anterior insula, but not in the homeostatic hypothalamus [42].

Animals perform many natural goal-oriented behaviours that result in pleasure and reinforcement. After eating and drinking, the next most common of these is sexual behaviour. Ghrelin has a partially characterised effect on hormonal reproductive physiology via actions on the hypothalamo-pituitary-gonadal axis. Ghrelin, like leptin, may be involved in the metabolic gating of the onset of puberty. For example, high plasma ghrelin levels may signal that insufficient energy is available for the demands of sexual maturation [43]. In contrast, much less is known about a potential 
role for ghrelin in sexual motivation and reward. In male mice administered an orexigenic dose of ghrelin, ultrasonic calling (a pre-copulatory courting behaviour) is reduced but the strong preference for females' bedding observed in controls is neither enhanced nor reduced by ghrelin administration [44]. For males, sexual behaviour is not particularly costly, so moderate hunger (reflected by levels of ghrelin high in the physiological range) may not be a sufficient obstacle to prevent males taking advantage of an opportunity to mate [45]. Nonetheless, it may be of interest to carefully determine the effects of ghrelin on a place preference conditioned by a receptive female or her odour, on sexual incentive motivation tests or on the latency or number of intromissions when male animals are allowed access to receptive females. In contrast to males, reproduction for females is extremely energetically expensive. In the context of reproduction perhaps energy stores are of more significance in females and sexual behaviours may be more susceptible to modification by energy balance signals. Indeed, fasting or acute but not chronic ghrelin treatment can reduce sexual receptivity in female rats [46].

\section{Conclusion: Ghrelin as a Reward Amplifier?}

From an evolutionary perspective, ghrelin signalling may provide a strong driving force to ensure both an adequate nutritional supply and a diversity of food of varying reward value. It makes physiological sense that the empty stomach signals to neurocircuits involved in food motivation and craving, but this system can be hijacked by obesogenic foods in the modern Western lifestyle, contributing strongly to the development of obesity. What is more, the effects of ghrelin on reward are not confined to natural rewards. Suppressed ghrelin signalling interrupts reward from chemical drugs of abuse such as alcohol [47], nicotine [48], cocaine and amphetamine [49]. Moreover, central ghrelin injection increases drug consumption and behaviours associated with the motivation for drugs. It should be noted, however, that ghrelin administration is itself rewarding, mice will show preference for an environment previously paired with ghrelin administration [50].

Possible targets for treatment by drugs modifying central ghrelin signalling are obesity, hypophagic diseases such as anorexia and forms of drug and alcohol abuse. The most prevalent of these is of course obesity. It is worthwhile noting that changes in circulating ghrelin are seen in obesity and after its treatment by bariatric surgery [51]. Furthermore, the concept of ghrelin resistance in homeostatic neural circuits after diet-induced obesity has been suggested [52], paralleling that of leptin resistance and insulin resistance manifesting as type 2 diabetes. Extending this idea to the motivation to eat, mice made obese by a high-fat diet are less motivated to obtain food rewards in basal conditions and after ghrelin treatment; diet-induced obesity suppresses the stimulatory effect of ghrelin compared to lean mice [53]. It can be argued whether a major physiological role of ghrelin is to drive hunger or prevent starvation 
but it is certain that ghrelin is orexigenic. Ghrelin's actions in food motivation complement this pro-feeding effect. It is clear that ghrelin is an important gut-brain signal for food intake driven by energy deficit or by an anticipated reward value.

\section{Acknowledgements}

Supported by the European Community's Seventh Framework Programme (FP7/2007-2013) under grant agreements No. 245009 (NeuroFAST, www.neurofast.eu), No. 266408 (Full4Health, www.full4health.eu) and $\mathrm{n}^{\circ} 241592$ (EurOCHIP, www.eurochip-obesity.com), the Swedish Research Council for Medicine (2011-3054 to K.P.S., 2009-S266 to S.L.D., 12208, 2009-2618), FOU/ ALF Göteborg (ALFGBG-138741), NovoNordisk Fonden and the Swedish Foundation for Strategic Research to Sahlgrenska Center for Cardiovascular and Metabolic Research (A305-188) 5-4328.

\section{References}

1 Volkow ND, Wang GJ, Telang F, Fowler JS, Thanos PK, Logan J, Alexoff D, Ding YS, Wong C, Ma Y, Pradhan K: Low dopamine striatal D2 receptors are associated with prefrontal metabolism in obese subjects: possible contributing factors. Neuroimage 2008;42:1537-1543.

2 Stice E, Yokum S, Blum K, Bohon C: Weight gain is associated with reduced striatal response to palatable food. J Neurosci 2010;30:13105-13109.

3 Stice E, Spoor S, Bohon C, Small DM: Relation between obesity and blunted striatal response to food is moderated by TaqIA A1 allele. Science 2008;322: 449-452.

-4 Geiger BM, Behr GG, Frank LE, Caldera-Siu AD, Beinfeld MC, Kokkotou EG, Pothos EN: Evidence for defective mesolimbic dopamine exocytosis in obesity-prone rats. FASEB J 2008;22:2740-2746.

5 Olds J: Self-stimulation of the brain: its use to study local effects of hunger, sex, and drugs. Science 1958; 127:315-324.

6 Johnson PM, Kenny PJ: Dopamine D2 receptors in addiction-like reward dysfunction and compulsive eating in obese rats. Nat Neurosci 2010;13:635-641.

7 Avena NM, Rada P, Hoebel BG: Evidence for sugar addiction: behavioral and neurochemical effects of intermittent, excessive sugar intake. Neurosci Biobehav Rev 2008;32:20-39.

8 van der Lely AJ, Tschöp M, Heiman ML, Ghigo E: Biological, physiological, pathophysiological, and pharmacological aspects of ghrelin. Endocr Rev 2004;25: 426-457.

9 Menzies JRW, Skibicka KP, Egecioglu E, Leng G, Dickson SL: Peripheral signals modifying food reward. Handb Exp Pharmacol 2012;209:131-158.
10 Scott V, McDade DM, Luckman SM: Rapid changes in the sensitivity of arcuate nucleus neurons to central ghrelin in relation to feeding status. Physiol Behav 2007;90:180-185.

11 Guan XM, Yu H, Palyha OC, McKee KK, Feighner SD, Sirinathsinghji DJ, Smith RG, Van der Ploeg LH, Howard AD: Distribution of mRNA encoding the growth hormone secretagogue receptor in brain and peripheral tissues. Brain Res Mol Brain Res 1997;48: 23-29.

12 Abizaid A, Liu ZW, Andrews ZB, Shanabrough M, Borok E, Elsworth JD, Roth RH, Sleeman MW, Picciotto MR, Tschöp MH, Gao XB, Horvath TL: Ghrelin modulates the activity and synaptic input organization of midbrain dopamine neurons while promoting appetite. J Clin Invest 2006;116:32293239.

13 Jerlhag E, Egecioglu E, Dickson SL, Douhan A, Svensson L, Engel JA: Ghrelin administration into tegmental areas stimulates locomotor activity and increases extracellular concentration of dopamine in the nucleus accumbens. Addict Biol 2007;12:6-16.

14 Kawahara Y, Kawahara H, Kaneko F, Yamada M, Nishi Y, Tanaka E, Nishi A: Peripherally administered ghrelin induces bimodal effects on the mesolimbic dopamine system depending on food-consumptive states. Neuroscience 2009;161:855-864.

15 Jerlhag E, Egecioglu E, Dickson SL, Andersson M, Svensson L, Engel JA: Ghrelin stimulates locomotor activity and accumbal dopamine-overflow via central cholinergic systems in mice: implications for its involvement in brain reward. Addict Biol 2006;11: $45-54$. 
16 Kojima M, Hosoda H, Date Y, Nakazato M, Matsuo $\mathrm{H}$, Kangawa K: Ghrelin is a growth-hormone-releasing acylated peptide from stomach. Nature 1999;402: 656-660.

17 Kojima M: The discovery of ghrelin - a personal memory. Regul Pept 2008;145:2-6.

18 Tschöp M, Smiley DL, Heiman ML: Ghrelin induces adiposity in rodents. Nature 2000;407:908-913.

19 Wren AM, Small CJ, Ward HL, Murphy KG, Dakin CL, Taheri S, Kennedy AR, Roberts GH, Morgan DG, Ghatei MA, Bloom SR: The novel hypothalamic peptide ghrelin stimulates food intake and growth hormone secretion. Endocrinology 2000;141:43254328.

20 Nakazato M, Murakami N, Date Y, Kojima M, Matsuo H, Kangawa K, Matsukura S: A role for ghrelin in the central regulation of feeding. Nature 2001;409: 194-198.

-21 Otto B, Cuntz U, Fruehauf E, Wawarta R, Folwaczny C, Riepl RL, Heiman ML, Lehnert P, Fichter M, Tschöp M: Weight gain decreases elevated plasma ghrelin concentrations of patients with anorexia nervosa. Eur J Endocrinol 2001;145:669-673.

-22 Tschöp M, Weyer C, Tataranni PA, Devanarayan V, Ravussin E, Heiman ML: Circulating ghrelin levels are decreased in human obesity. Diabetes 2001;50: 707-709.

-23 Skibicka KP, Dickson SL: Ghrelin and food reward: the story of potential underlying substrates. Peptides 2011;32:2265-2273.

-24 Wren AM, Small CJ, Abbott CR, Dhillo WS, Seal LJ, Cohen MA, Batterham RL, Taheri S, Stanley SA, Ghatei MA, Bloom SR: Ghrelin causes hyperphagia and obesity in rats. Diabetes 2001;50:2540-2547.

-25 Asakawa A, Inui A, Kaga T, Yuzuriha H, Nagata T, Ueno N, Makino S, Fujimiya M, Niijima A, Fujino MA, Kasuga M: Ghrelin is an appetite-stimulatory signal from stomach with structural resemblance to motilin. Gastroenterology 2001;120:337-345.

26 Naleid AM, Grace MK, Cummings DE, Levine AS: Ghrelin induces feeding in the mesolimbic reward pathway between the ventral tegmental area and the nucleus accumbens. Peptides 2005;26:2274-2279.

27 Skibicka KP, Hansson C, Alvarez-Crespo M, Friberg PA, Dickson SL: Ghrelin directly targets the ventral tegmental area to increase food motivation. Neuroscience 2011;180:129-137.

28 Holst B, Cygankiewicz A, Jensen TH, Ankersen M, Schwartz TW: High constitutive signaling of the ghrelin receptor - identification of a potent inverse agonist. Mol Endocrinol 2003;17:2201-2210.

29 Jiang H, Betancourt L, Smith RG: Ghrelin amplifies dopamine signaling by cross talk involving formation of growth hormone secretagogue receptor/dopamine receptor subtype 1 heterodimers. Mol Endocrinol 2006;20:1772-1785.
30 Lenoir M, Serre F, Cantin L, Ahmed SH: Intense sweetness surpasses cocaine reward. PLoS One 2007; 2:e698.

31 Egecioglu E, Jerlhag E, Salomé N, Skibicka KP, Haage D, Bohlooly-Y M, Andersson D, Bjursell M, Perrissoud D, Engel JA, Dickson SL: Ghrelin increases intake of rewarding food in rodents. Addict Biol 2010;15:304-311.

32 Disse E, Bussier AL, Deblon N, Pfluger PT, Tschöp MH, Laville M, Rohner-Jeanrenaud F: Systemic ghrelin and reward: effect of cholinergic blockade. Physiol Behav 2011;102:481-484.

33 Perello M, Sakata I, Birnbaum S, Chuang JC, Osborne-Lawrence S, Rovinsky SA, Woloszyn J, Yanagisawa M, Lutter M, Zigman JM: Ghrelin increases the rewarding value of high-fat diet in an orexin-dependent manner. Biol Psychiatry 2010;67:880-886.

34 Tordoff MG, Alarcon LK, Lawler MP: Preferences of 14 rat strains for 17 taste compounds. Physiol Behav 2008;95:308-332.

35 Domingos AI, Vaynshteyn J, Voss HU, Ren X, Gradinaru V, Zang F, Deisseroth K, de Araujo IE, Friedman J: Leptin regulates the reward value of nutrient. Nat Neurosci 2011;14:1562-1568.

36 Disse E, Bussier AL, Veyrat-Durebex C, Deblon N, Pfluger PT, Tschöp MH, Laville M, Rohner-Jeanrenaud F: Peripheral ghrelin enhances sweet taste food consumption and preference, regardless of its caloric content. Physiol Behav 2010;101:277-281.

37 Skibicka KP, Hansson C, Egecioglu E, Dickson SL: Role of ghrelin in food reward: impact of ghrelin on sucrose self-administration and mesolimbic dopamine and acetylcholine receptor gene expression. Addict Biol 2012;17:95-107.

38 Weinberg ZY, Nicholson ML, Currie PJ: 6-Hydroxydopamine lesions of the ventral tegmental area suppress ghrelin's ability to elicit food-reinforced behavior. Neurosci Lett 2011;499:70-73.

39 Skibicka KP, Shirazi RH, Hansson C, Dickson SL: Ghrelin interacts with neuropeptide Y Y1 and opioid receptors to increase food reward. Endocrinology 2012;153:1194-1205.

40 Verhagen LA, Egecioglu E, Luijendijk MC, Hillebrand JJ, Adan RA, Dickson SL: Acute and chronic suppression of the central ghrelin signaling system reveals a role in food anticipatory activity. Eur Neuropsychopharmacol 2011;21:384-392.

41 Merkestein M, Brans MA, Luijendijk MC, de Jong JW, Egecioglu E, Dickson SL, Adan RA: Ghrelin mediates anticipation to a palatable meal in rats. Obesity (Silver Spring) 2012;20:963-971.

42 Malik S, McGlone F, Bedrossian D, Dagher A: Ghrelin modulates brain activity in areas that control appetitive behavior. Cell Metab 2008;7:400-409. 
43 Roa J, García-Galiano D, Castellano JM, Gaytan F, Pinilla L, Tena-Sempere M: Metabolic control of puberty onset: new players, new mechanisms. Mol Cell Endocrinol 2010;324:87-94.

44 Shah SN, Nyby JG: Ghrelin's quick inhibition of androgen-dependent behaviors of male house mice (Mus musculus). Horm Behav 2010;57:291-296.

45 Caquineau C, Leng G, Douglas AJ: Sexual behaviour and neuronal activation in the vomeronasal pathway and hypothalamus of food-deprived male rats. J Neuroendocrinol 2012;24:712-723.

46 Bertoldi ML, Luque EM, Carlini VP, Vincenti LM, Stutz G, Santillán ME, Ruiz RD, Fiol de Cuneo M, Martini AC: Inhibitory effects of ghrelin on sexual behavior: role of the peptide in the receptivity reduction induced by food restriction in mice. Horm Metab Res 2011;43:494-499.

47 Jerlhag E, Egecioglu E, Landgren S, Salomé N, Heilig M, Moechars D, Datta R, Perrissoud D, Dickson SL, Engel JA: Requirement of central ghrelin signaling for alcohol reward. Proc Natl Acad Sci USA 2009; 106:11318-11323.

48 Jerlhag E, Engel JA: Ghrelin receptor antagonism attenuates nicotine-induced locomotor stimulation, accumbal dopamine release and conditioned place preference in mice. Drug Alcohol Depend 2011;117: $126-131$.
49 Jerlhag E, Egecioglu E, Dickson SL, Engel JA: Ghrelin receptor antagonism attenuates cocaine- and amphetamine-induced locomotor stimulation, accumbal dopamine release, and conditioned place preference. Psychopharmacology 2010;211:415-422.

50 Jerlhag E: Systemic administration of ghrelin induces conditioned place preference and stimulates accumbal dopamine. Addict Biol 2008;13:358-363.

51 Cummings DE, Weigle DS, Frayo RS, Breen PA, Ma MK, Dellinger EP, Purnell JQ: Plasma ghrelin levels after diet-induced weight loss or gastric bypass surgery. N Engl J Med 2002;346:1623-1630.

52 Briggs DI, Enriori PJ, Lemus MB, Cowley MA, Andrews ZB: Diet-induced obesity causes ghrelin resistance in arcuate NPY/AgRP neurons. Endocrinology 2010;151:4745-4755.

53 Finger BC, Dinan TG, Cryan JF: Diet-induced obesity blunts the behavioural effects of ghrelin: studies in a mouse-progressive ratio task. Psychopharmacology (Berl) 2012;220:173-181.

John R.W. Menzies

Centre for Integrative Physiology

School of Biomedical Sciences, University of Edinburgh

Edinburgh, EH8 9XD (UK)

E-Mail john.menzies@ed.ac.uk 